\title{
Effect of Swimming on Serum Irisin Levels in Experimentally- Induced Rat Model of Postmenopausal Osteoporosis
}

\author{
MOHAMMED A. EL-GHANNAM, M.D.; KAMELIA I. ATTIA, M.D.; MARWA A. HABIB, M.D. and \\ LAMIAA G. MOHAMMED, M.Sc.
}

The Department of Physiology, Faculty of Medicine, Zagazig University

\begin{abstract}
Background: Irisin is a new myokine that has been linked to many metabolic diseases. Postmenopausal osteoporosis is a metabolic disease manifested by decreased bone mineral density; and physical exercise may play a role in its prevention and treatment. The relationship between irisin and physical exercise, and the role of irisin in osteoporosis are not clear yet.

Aim of Study: The present study was performed to clarify the effect of swimming training on serum irisin levels in a rat model of postmenopausal osteoporosis induced in female albino rats.

Material and Methods: Forty eight adult female rats were divided into 4 equal groups: Control (CONT), swimming (SWIM), ovariectomized (OVX), and ovariectomized plus swimming (OVX + SWIM). Serum levels of irisin, estradiol, calcium, phosphorus alkaline phosphatase, and bone calcium, phosphorus, and femoral ash weights were measured and histopathological examination of femoral bones were performed in all groups.

Results: Serum irisin levels were significantly increased in SWIM group compared with CONT group, and decreased in OVX group compared with CONT and SWIM groups. In OVX + SWIM group, they were significantly increased compared with those of CONT and OVX groups; but, insignificantly changed compared with SWIM group. Positive correlations were found between serum irisin and serum levels of estradiol, bone calcium and phosphorus, femoral bone ash weights in all groups; and with serum alkaline phosphatase in SWIM and OVX + SWIM groups.

Conclusion: Swimming training increased serum irisin levels in ovariectomized rats and guarded against the occurrence of osteoporotic changes. So, the beneficial effects of swimming training on bone may be mediated by irisin.
\end{abstract}

Key Words: Irisin - Osteoporosis - Physical exercise.

\section{Introduction}

IRISIN is a newly discovered hormone-like myokine that consists of 112 amino acid residues and

Correspondence to: Dr. Marwa A. Habib.

E-Mail: marwahabib2015@gmail.com was reported to be synthesized in muscle tissue after proteolytic cleavage of its precursor, fibronectin type III domain containing protein 5 (FNDC5) by unknown protease [1]. Several studies revealed marked distribution of irisin in human tissues as adipose tissue, liver, cardiovascular system, brain, bone, pancreas, kidney, immune system, ovary, peripheral myelin sheath and pancreatic islets $[2,3]$ Irisin was reported to be involved in inducing browning of adipose tissue, expression of Uncoupling Protein 1 (UCP-1) and improvement of systemic metabolism by increasing energy expenditure $[\mathbf{1 , 4 , 5}]$

Postmenopausal osteoporosis is a bone metabolic disease occurring in old females and manifested by reduced bone mineral density and increased risk of fractures $[6,7]$. The mass and strength changes that occur in cancellous bones of ovariectomized rats mimic the bone changes of menopausal women $[8]$. Although genetic factors are the primary determinant of osteoporosis [9], physical exercise is submitted as one of the important protocols for prevention and treatment of osteoporosis [10,11]. The mechanisms of the anabolic effects exerted by physical exercise on bone are not clear yet, however, they were assumed to be exerted either via direct muscle force-generated mechanical signals or via indirect endocrine regulation [12]. Contradictory reports were found about the beneficial effects of swimming exercise on the bones where some studies disapproved its ability to prevent bone loss alone [13,14]; while, other studies confirmed its beneficial effects in ovariectomized rats $[15,16]$. Few studies investigated the role of irisin in bone metabolism and its relationship to bone changes that accompany osteoporosis, but the results are not established yet. Also, the experimental studies regarding the influence of physical exercise on FNDC5 expression in muscles and 
irisin levels in muscle and serum are limited and controversial.

Therefore, the present study was performed to explore the effect of swimming training on serum levels of irisin in ovariectomized adult female albino rat as a model of postmenopausal osteoporosis.

\section{Material and Methods}

\section{Animals:}

The study was performed in the period from 5th March to 25 th June 2016 in the Animal House of Faculty of Medicine, Zagazig University. A total number of 48 healthy adult female albino rats of a local strain weighing 200-250g were purchased from the Animal House of Faculty of Medicine, Zagazig University. The rats were housed 5 rats per cage in steel wire cages $(50 \mathrm{~cm} \mathrm{X} 60 \mathrm{~cm} \mathrm{X}$ $60 \mathrm{~cm}$ ) at comfortable room temperature, under controlled condition of light (12h dark and $12 \mathrm{~h}$ light) and under hygienic conditions. All rats were provided free access to food and water and fed the same type of food that consisted of mixed commercial rat laboratory chow. The rats were left for one week prior to the beginning of the experiments for adaptation to laboratory conditions. All the procedures in the study were permitted by the Institutional Research Board and Ethics Committee of Faculty of Medicine, Zagazig University.

\section{Methods:}

Grouping of animals: The forty eight adult female albino rats were randomized after the adaptation period and divided into 4 equal groups: Control sedentary group (CONT), swimming exercise group (SWIM), ovariectomized sedentary group (OVX) in which rats were bilaterally ovariectomized for induction of a rat model of postmenopausal osteoporosis, and ovariectomized plus swimming exercise group (OVX + SWIM).

Ovariectomy technique: For induction of rat model of postmenopausal osteoporosis, ovariectomy was performed according to Irahara et al. [17] The rats were anaesthetized by intraperitoneal injection of pentobarbital sodium $(40 \mathrm{mg} / \mathrm{kg}$ body weight; Misr CO. Pharm. Ind. S.A.A. Materia, Egypt) after overnight fasting, and then tied to the operating board where hair was removed from the lower abdomen by a small curved scissor and the bared skin was sterilized by $70 \%$ ethyl alcohol (ADWIC Laboratory Chemicals, Egypt). A midline incision was made through the skin and the abdominal wall, the ovaries and fallopian tubes were located. The fallopian tubes were tied and the ovaries were removed. The viscera were restored and the abdominal wall incision was repaired with catgut thread, then the skin incision was repaired with silk suture. Garamycin cream (Misr Co. Pharm. Ind. S.A.A. Materia, Egypt) was put over the closed incision and covered with sterile gauze. Rats were observed until the recovery from anesthesia and ampicillin sodium $(25 \mathrm{mg} / \mathrm{kg}$, IM; Misr CO. Pharm. Ind. S.A.A. Materia, Egypt) was given to guard against post-operative infections. The rats in CONT and SWIM groups were exposed to sham operations with the same procedure of ovariectomy without removal of the ovaries. In swimming groups, the training started one week after recovery from surgery.

Exercise protocol: Exercise was performed in a swimming tank $(120 \times 50 \mathrm{~cm}$ tank containing $38 \mathrm{~cm}$ height of water at $30 \pm 1^{\circ} \mathrm{C}$ ) at the same time of the day. Rats were habituated to the swimming exercise during the first week. Initially, rats swam for $15 \mathrm{~min}$, with increasing of additional $15 \mathrm{~min}$ daily, until a swimming period of one hour was attained. Subsequently, a daily swimming period of one hour, 5 days/week, was maintained for 8 weeks. At the end of each exercise session, animals were dried and kept in a warm environment. Rats were sacrificed $48 \mathrm{hrs}$ after last exercise session to minimize acute effects of exercise [18].

Determination of sexual cycle: Vaginal secretions were obtained by inserting the tip of a plastic pipette filled with $10 \mathrm{~mL}$ of $\mathrm{NaCl} 0.9 \%$ into the vagina of the non-ovariectomized rats. Then the collected material was observed without staining under a light microscope. According to Marcondes et al., cycles with duration of 4-5 days were considered regular [19].

Blood sampling: Blood samples were collected from non-ovariectomized groups in the afternoon of estrous day of their cycles after an overnight fasting to avoid circadian rhythm of serum hormonal levels. The samples were collected from the retro orbital plexus of rats under ether anesthesia (ADWIC Laboratory Chemicals, Egypt) using glass capillaries in clean centrifuge tubes and allowed for clotting, and then serum was separated by centrifugation of blood for 10 minutes at 3000rpm. The supernatant sera were pipetted off using fine tipped automatic pipettes and then kept frozen at $-20^{\circ} \mathrm{C}$ till used for estimation of the following parameters in all groups:

Serum levels of irisin: Using rat irisin ELISA Kits (SunRed Biotechnology Company, Shanghai, China) according to Bostrom et al. [1] . 
Serum levels of estradiol: Using rat ELISA kits; Catalog number BC-1111 (BioCheck Inc 323 Vintage Park Dr. Foster City, CA 94404) according to Tietz [20]

Serum levels of calcium: By colorimetric method using spectronic 21 UVD spectrophotometer (Bausch and Lamb, U.S.A.) according to Gindler et al. [21].

Serum levels of phosphorus: By colorimetric method according to Goldenberg and Fernfindez

Serum levels of alkaline phosphatase: By colorimetric method according to Belfield and Goldberg

Bone ashing: According to the dry ashing procedure described by Doster et al. [24], the right femur bones of the ether-anesthetized rats were finely dissected and cleaned of from adhering tissue. The whole bones were extracted two times with a 1:1 mixture of absolute ethanol and diethyl ether for $48 \mathrm{~h}$ and one time with diethyl ether for $24 \mathrm{~h}$. The dehydrated and defatted bones were dried in $80^{\circ} \mathrm{C}$ oven for $48 \mathrm{~h}$, and then ashed in a muffle furnace at $600^{\circ} \mathrm{C}$ for 48 hours after putting each bone in a clean porcelain dish. After that, bone ash weights were measured, and then hydrolyzed in 6 N HCL for determination of calcium and phosphorus concentrations by the colorimetric methods described before.

Bone histopathological sections: The left femur bones of ether-anesthetized rats were removed, cleaned of adhering soft tissue, fixed and placed in $10 \%$ formalin solution for one day [25]. Then tissues were processed in ascending grades of alcohol, cleaned in xylol and embedded in paraffin blocks. Four-microns sections were cut on a standard rotatory microtome, stained by heamatoxylin and eosin stain (H \& E) and observed for histopathological changes as described by Bancroft and Cook [26].

Statistical analysis: The statistical analysis was done by using Statistical Package for the Social Science; SPSS program, Version 19 (SPSS Inc. Chicago, IL, USA). Values were given as mean \pm SD. ANOVA followed by LSD post hoc statistical test was used for comparison of means of the variables in different groups. Pearson's correlation (r) analysis was performed to demonstrate possible relationships between serum levels of irisin and the measured parameters. $p$-value $<0.05$ was regarded as statistically significant for all statistical tests.

\section{Results}

Serum parameters [data shown in (Table 1)]:

Regarding serum levels of irisin, they weresignificantly increased in SWIM group compared with those of CONT group $(p<0.01)$. In OVX group, they showed a statistically significant decrease when compared with those of CONT group $(p<0.05)$ and SWIM group $(p<0.001)$. In OVX + SWIM group, they were significantly increased compared with those of CONT and OVX groups $(p<0.001)$, while, they showed insignificant change compared with those of SWIM group $(p>0.05)$.

As regard serum levels of estradiol, there was a statistically significant decrease in OVX group compared with those of CONT and SWIM groups $(p<0.001)$; while, no significant changes were found between the levels in SWIM group when compared with those of CONT group $(p>0.05)$. In OVX + SWIM group, they were significantly decreased compared with those of CONT and SWIM groups $(p<0.001)$, while, they showed insignificant change compared with those of OVX group ( $p$ $>0.05$ ). Also, statistically significant positive correlations were found between serum levels of irisin and estradiol in all groups.

Concerning serum levels of calcium, they were significantly increased in SWIM group when compared with those of CONT group $(p<0.05)$. In OVX group, they showed a statistically insignificant change when compared with those of CONT group $(p>0.05)$ and a statistically significant decrease when compared with those of SWIM group ( $p$ $<0.001)$. In OVX + SWIM group, they were significantly increased compared with those of OVX group $(p<0.05)$, while, they showed insignificant change compared with those of CONT and SWIM groups $(p>0.05)$. Additionally, no statistically significant correlations were found between serum levels of irisin and calcium in all groups.

As regard serum levels of phosphorus, there was a statistically significant increase in SWIM group when compared with those of CONT group $(p<0.05)$. In OVX group, there was a statistically insignificant change when compared with those of CONT group $(p>0.05)$, but they were significantly decreased when compared to those of SWIM group $(p<0.01)$. In OVX + SWIM group, they were significantly increased compared with those of CONT and OVX groups ( $p<0.01, p<0.001$ respectively), while, they showed insignificant change compared with those of swim group $(p>0.05)$. No statistically significant correlations were found between serum levels of irisin and phosphorus in all groups. 
Regarding serum levels of alkaline phosphatase, they were significantly increased in SWIM and OVX groups when compared with those of CONT group $(p<0.001)$; however, no statistically significant changes were found in OVX group compared with those of SWIM group $(p>0.05)$. In OVX + SWIM group, they were significantly increased compared with those of CONT and OVX groups $(p<0.001, p<0.05$ respectively), while, they showed insignificant change compared with those of swim group ( $p>0.05)$. No statistically significant correlations were found between serum levels of irisin and alkaline phosphatase in CONT and OVX groups; while they were positively correlated in SWIM and OVX + SWIM groups.

\section{Bone parameters [data shown in (Table 1)]:}

As regard bone calcium concentrations, they were significantly increased in SWIM group when compared with those of CONT group $(p<0.01)$ and significantly decreased in OVX group when compared with those of CONT and SWIM groups $(p<0.01, p<0.001$ respectively $)$. In OVX + SWIM group, they were significantly decreased compared with those of SWIM group ( $p<0.001)$, and significantly increased compared with those of OVX group $(p<0.05)$, while, they showed insignificant change compared with those of CONT group ( $p$ $>0.05$ ). Also, statistically significant positive correlations were found between serum levels of irisin and bone calcium concentrations in all groups.

Concerning bone phosphorus concentrations, there was a statistically significant increase in SWIM group when compared with those of CONT group $(p<0.001)$ and a significant decrease in OVX group when compared with those of CONT and SWIM groups $(p<0.01, p<0.001$ respectively). In OVX + SWIM group, they were significantly decreased compared with those of SWIM group $(p<0.01)$, and significantly increased compared with those of OVX group $(p<0.001)$, while, they showed insignificant change compared with those of CONT group ( $p>0.05)$. Statistically significant positive correlations were found between serum levels of irisin and bone phosphorus concentrations in all groups.

Table (1): Comparison between the levels of the measured parameters in all groups.

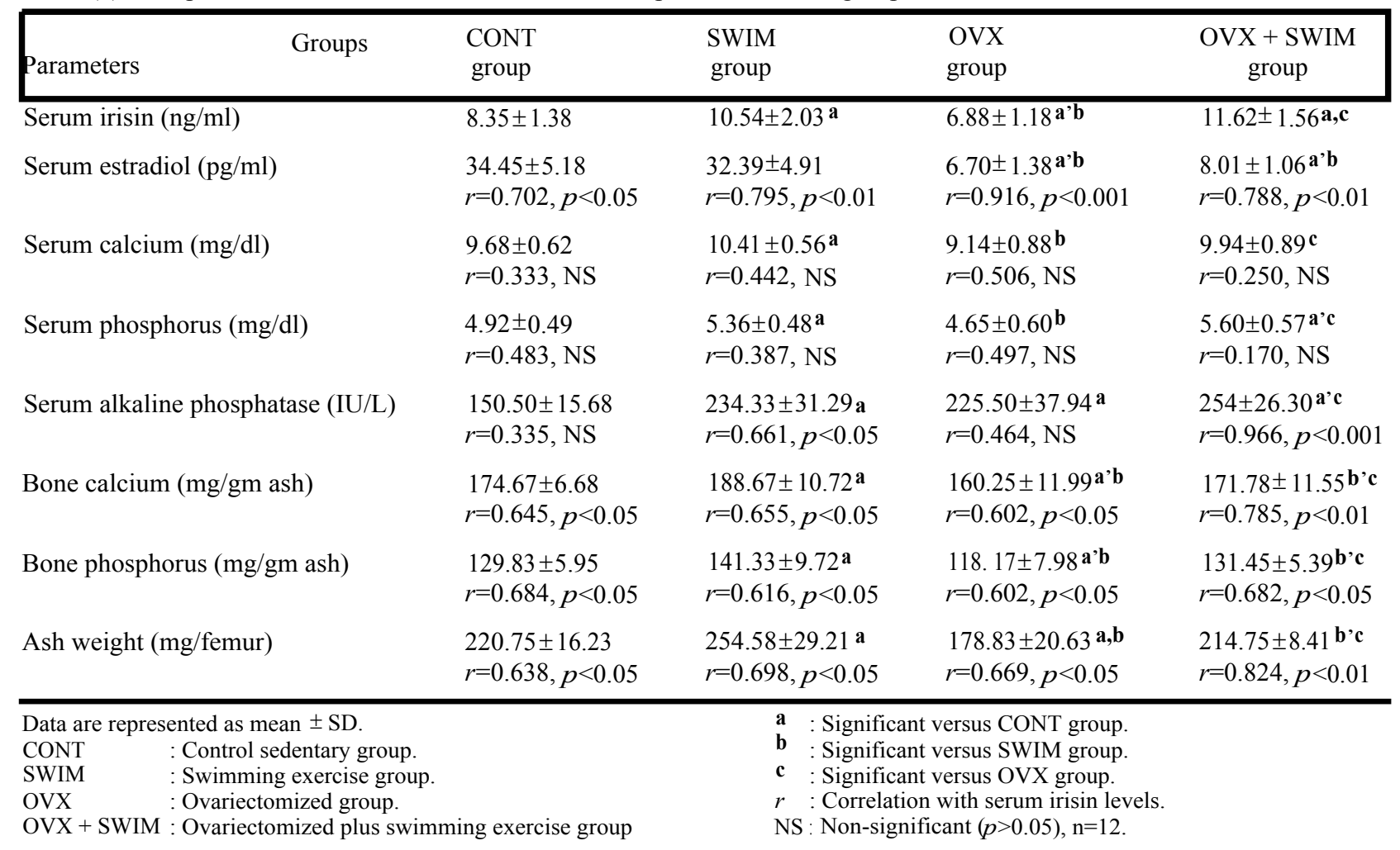

Regarding femoral bone ash weights, they were significantly increased in SWIM group compared with those of CONT group $(p<0.001)$ and significantly decreased in OVX group compared with CONT and SWIM groups $(p<0.001)$. In OVX +
SWIM group, they were significantly decreased compared with those of SWIM group $(p<0.001)$, and significantly increased compared with those of OVX group $(p<0.001)$, while, they showed insignificant change compared with those of CONT 
group ( $p>0.05$ ). Also, statistically significant positive correlations were found between serum levels of irisin and femoral bone ash weights in all groups.

Histopathological bone study Fig. (1):

The Histopathological studies on the lower end of rats' femur bones showed normal bone tissue

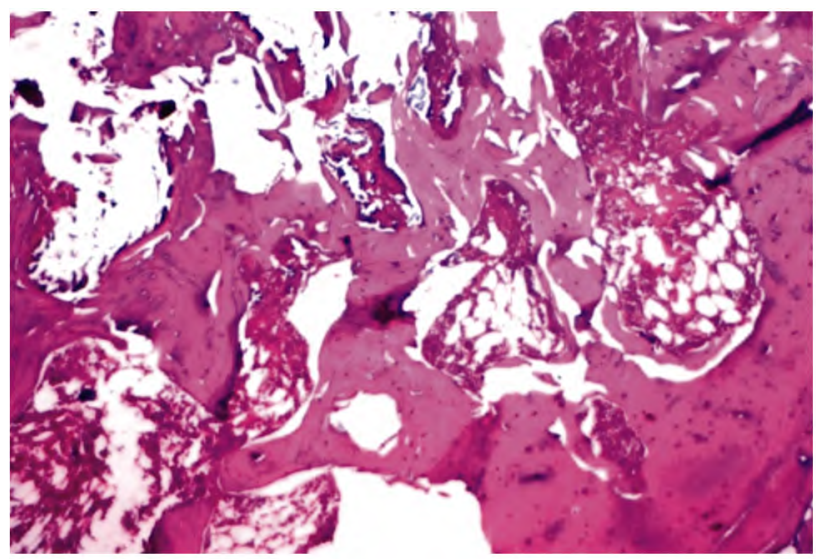

(A)

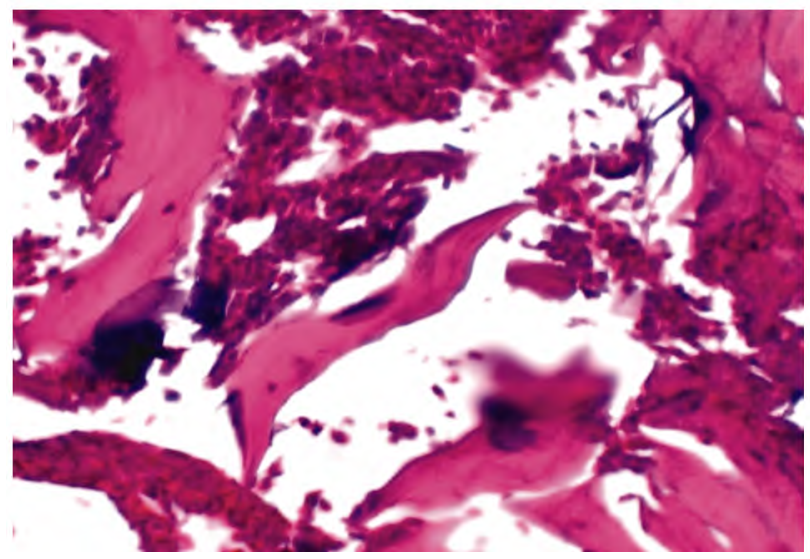

(C) with parallel arrangement of bone trabeculae in CONT group, thick bone trabeculae with decreased marrow area between them in SWIM group, widely separated, thin-walled bone trabeculae with widened inter trabecular spaces and increased number of osteoclasts in the OVX group, and averagesized bone trabeculae in OVX + SWIM group.

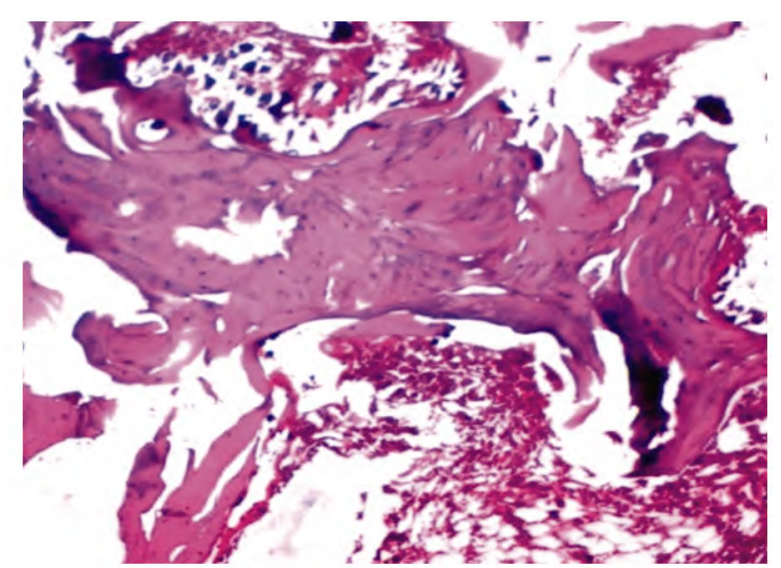

(B)

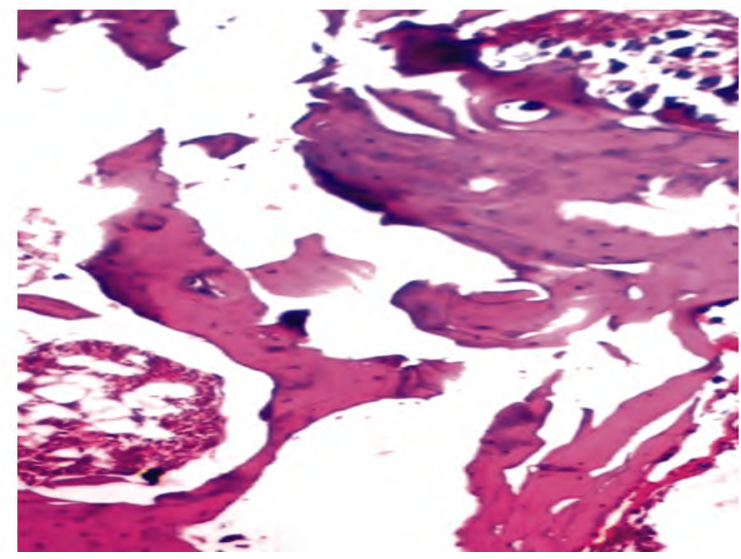

(D)

Fig. (1): Photomicrographs of the lower end of rat femur from the studied groups (H \& E stain *250). (A): (CONT; control sedentary group), (B): (SWIM; swimming exercise group), (C): (OVX; ovariectomized group), (D): (OVX + SWIM; ovariectomized plus swimming exercise group).

\section{Discussion}

In a part of the present study, the adult female albino rats were bilaterally ovariectomized and kept for eight weeks to induce a rat model of postmenopausal osteoporosis. The statistical analysis revealed a significant reduction in serum levels of estradiol in the OVX group when compared to those of the CONT group which ascertained the presence of ovarian deficiency. This finding is in agreement with other studies that demonstrated reduction in serum levels of estradiol after ovariectomy [27-29] .

The present study revealed statistically insignificant changes in serum levels of both calcium and phosphorus in OVX group when compared to CONT group. Consistent with our finding, the study by Palermo et al., showed no difference in serum levels of both calcium and phosphorus between postmenopausal osteoporotic and nonosteoporotic women [30]. In addition, Kawakita et al. did not find any difference in serum levels of both calcium and phosphorus between ovariectomized and control groups, and they attributed these non-significant changes to the increase in urinary calcium and phosphorus excretion together with the increase in bone turnover in the ovariectomized rats [31]. Also, it was reported that menopause is associated with decreased intestinal calcium absorption [32]. In contrast to our finding, other 
studies revealed a significant reduction in serum levels of both calcium and phosphorus in the ovariectomized group when compared to those of the sham operated group $[33,34]$.

The present study demonstrated a statistically significant reduction in the femoral bone concentrations of both calcium and phosphorus and femoral bone ash weights in the OVX group when compared to those of the CONT group. In agreement with our finding, Shiraishi et al., reported a significant decrease in bone mineral density in ovariectomized group in comparison to control group [33]. Moreover, the study by Abuohashish et al. demonstrated a reduction in bone calcium and phosphorus concentrations and femoral bones ash weights in osteoporotic group when compared to control one. They attributed these changes to the increase in osteoclastic bone resorption activities induced by increased cytokines as a result of estrogen deficiency [35].

The present study revealed a statistically significant increase in serum levels of alkaline phosphatase; as a marker of osteoblastic activity and bone formation; in the OVX group when compared to those of the CONT group. In agreement with our finding, some studies revealed a significant increase in serum levels of alkaline phosphatase in ovariectomized groups when compared to control groups $[\mathbf{2 9 , 3 5}$. These increased levels were proposed to be due to the micro architectural changes and increased bone remodeling that resulted from estrogen deficiency [36] which increases the production of both osteoblasts and osteoclasts, and the imbalance between bone formation and resorption lead to osteoporosis $[\mathbf{3 7 , 3 8}]$. This imbalance was proposed to be due to either an increase in the lifespan of osteoclasts [39] or shortening of the lifespan of osteoblasts [40] associated with estrogen deficiency. In contrast to our finding, an in vitro study revealed increased levels of alkaline phosphatase associated with the increase in the level of estrogen in osteoblastic cells [41]

To confirm the occurrence of osteoporosis in OVX group, histopathological examination of femoral bones was performed and revealed widely separated, thin-walled bone trabeculae with widened inter trabecular spaces and increased number of osteoclasts in OVX group in comparison to CONT group which revealed normal bone tissue with parallel arrangement of bone trabeculae. These findings are consistent with the histopathological findings demonstrated in other studies $[35,42]$.

To assess the relationship between irisin and osteoporotic changes that were detected in the
OVX group, serum levels of irisin were measured and were significantly decreased when compared with those of the CONT group. Also, statistically significant positive correlations were found between serum levels of irisin and estradiol in both CONT and OVX groups. These findings come in line with other studies which revealed lower levels of serum irisin in postmenopausal women with previous osteoporotic fractures $[\mathbf{3 0 , 4 3 , 4 4}]$. Additionally, Huh et al., reported a significant positive correlation between circulating irisin and estradiol and suggested that estradiol may induce irisin secretion either directly or through anabolic pathways to increase muscle mass and up regulates irisin [45] The reduction in serum levels of irisin; which is considered as a myokine; was explained by the sarcopenia that results from estrogen deficiency [46]. Another explanation for the decreased serum levels of irisin in the ovariectomized rats is the increased visceral fat content which was reported to be negatively correlated with irisin [47]. In contrast to these findings, Zugel et al., reported that serum levels of irisin were significantly increased after ovariectomy and attributed this elevation to the molecular pathways associated with ovariectomy that stimulate chronic elevations in serum irisin as a compensatory mechanism in the early postmenopausal period [48]

The present study revealed statistically insignificant correlations between serum levels of irisin and serum levels of both calcium and phosphorus in CONT and OVX groups. However, statistically significant positive correlations were found between serum levels of irisin and bone concentrations of calcium and phosphorus and femoral bone ash weights in CONT and OVX groups. In agreement with our findings, a positive correlation was reported between serum levels of irisin and bone mineral density [49-52]. In contrast, other studies revealed insignificant correlations between serum levels of irisin and bone mineral density in postmenopausal women with previous osteoporotic fractures $[30,46]$

In the present study, we induced a rat model of 8 -week course of swimming training in the adult female albino rats. The expected changes in the SWIM group were assessed by measuring the serum levels and bone femoral concentrations of both calcium and phosphorus and femoral bone ash weights. The statistical analysis revealed significant increases in the levels of all of the previous parameters in SWIM group when compared to those of the CONT group. These findings are consistent with the study by Piri et al., which revealed an increase in serum levels of calcium and phosphorus 
and bone mineral density in exercise group compared with control group [53]. Also, eight-weeks swimming training was found to enhance plasma calcium content and improve calcium absorption [54]. Moreover, it was reported that exposure of young rats to exercise stimulated bone growth with subsequent increase in the demand for minerals that was satisfied by an increase in serum Vitamin D3 level as well as increased intestinal absorption of calcium with depressed parathyroid hormone production [55]. This increase in bone minerals was suggested to be due to the increase in the osteoblasts with consequent increase in bone formation and mineralization [56]. In contrast to our findings, the study by Veigh et al., revealed insignificant difference in serum levels of calcium between swimming and control groups [57]. Also, a swimming regimen of shorter duration (4 weeks) in young female rats resulted in decreases in femoral and tibial mineral density [58]

The present study revealed a statistically significant increase in serum levels of alkaline phosphatase in SWIM group in comparison to CONT group. This finding comes in line with the study by Swissa-Sivan et al., which demonstrated increased serum levels of alkaline phosphatase in exercise group compared to control one and explained this rise by the enhancement of osteoblastic activity in the bone tissue [59]. Osteoblasts were reported to secrete large amounts of alkaline phosphatase when they are actively depositing bone where some of this enzyme reaches the blood giving a good index of bone formation [60]. Moreover, exercise has been shown to induce differentiation of bone marrow Mesenchymal Stem Cells (MSCs) towards osteoblasts which is manifested by an increase in the activities of alkaline phosphatase [61]

The histopathological studies of femoral bones of SWIM group revealed thickening of the bone trabeculae with decrease in the marrow area between them in comparison to CONT group, which are consistent with some studies $[15,59]$ but disagree with another study that revealed higher bone loss in young female rats exposed to intensive swimming exercises [13].

In the present study, the statistical analysis revealed a significant increase in serum levels of irisin in SWIM group when compared to those of CONT group. Consistent with our finding, Lu et al., reported that serum levels of irisin were higher in exercise rat groups than those in sedentary rat groups [62]. Also, serum levels of irisin were increased after an 8-week course of cycling exercise in middle aged/older training group [47]. Additionally, the study by Boström et al., demonstrated increased irisin levels after a 3-week course of free-wheel running in mice and a 10-week course of endurance training in healthy adults. The increased irisin levels were attributed to the increase of peroxisome proliferator-activated receptor gamma coactivator-1-alpha (PGC-1 a) expression in skeletal muscles, which enhanced FNDC5 splicing of to form irisin [1]. Also, it may be attributed to the increase in muscle mass after exercise as irisin was reported to correlate with muscle mass [63]

In contrast to the present study, Jafari \& Farzaneghi reported an insignificant increase in the plasma levels of irisin and FNDC5 of rats' heart tissue and muscle following an 8-week course of aerobic swimming exercise [64]. Additionally, Fain et al., did not detect any increase in FNDC5 mRNA and protein in skeletal muscle and serum levels of irisin after prolonged training in normal pigs [65] Moreover, the meta-analysis of the randomized controlled trials in adult persons revealed a significant decrease in circulating levels of irisin after chronic exercise training [66]. Also, serum irisin levels showed a statistically insignificant difference in male adolescent swimmers compared with sedentary controls [67]

The present study revealed statistically significant positive correlations between serum levels of irisin and serum levels of alkaline phosphatase and bone concentrations of calcium and phosphorus and femoral bone ash weights in SWIM group. Our finding comes in line with Colaianni et al., who reported an increase in the number of alkaline phosphatase positive colonies in the conditioned medium obtained from myoblasts of mice after wheel exercise [68]

In the present study we investigated the effect of swimming training on ovariectomized rats. The statistical analysis revealed significant increases in serum levels of calcium, phosphorus, alkaline phosphatase, and bone concentrations of calcium, phosphorus, and femoral bone ash weight in OVX + SWIM group compared with OVX group. Also, the osteoporotic changes demonstrated by histopathological examination of femur bones in OVX group were ameliorated in OVX + SWIM group. The effect of swimming exercise on the osteoporotic bone is still a matter of controversy. In this regard, Tsukahara et al., reported that water activities is important for preventing loss of bone mass [69]. Additionally, the study by Hart et al., demonstrated that 12-week swimming exercise had a significant effect on bones of ovariectomized rats 
that was confirmed by a greater bone mineral density and higher mechanical properties in trained compared with control rats [16]. Moreover, the study by Ooi et al., showed a significantly higher total bone mineral density and improved bone microstructure in ovariectomized-swimming group when compared to the ovariectomized-control group [15]. In contrast, other studies did not find good correlation between swimming exercise and bone mineral density in ovariectomized rats $[\mathbf{7 0 , 7 1 ]}$

The present study found that serum levels of irisin were significantly increased in OVX + SWIM group compared with OVX group, and were positively correlated with bone concentrations of calcium, phosphorus, and femoral bone ash weight in OVX + SWIM group. These positive correlations were proposed to be an indication for the stimulatory effect of irisin on osteoblast differentiation and consequently increase of alkaline phosphatase with subsequent increase of bone mineralization and weight. This stimulatory effect guarded against the osteoporotic changes that occur in ovariectomized rats as proved by biochemical analysis and histopathological examination. Consistent with our suggestion, an in vitro study demonstrated that osteoblast proliferation and expression of osteoblast differentiation markers, including alkaline phosphatase were enhanced by irisin that increased also deposition of calcium in cultured osteoblast [72] Moreover, a recent study demonstrated the inhibitory effect of irisin on osteoclast differentiation [73].

\section{In Conclusion:}

Postmenopausal osteoporosis induced experimentally in adult female albino rats was associated with decreased serum levels of irisin. Swimming training of ovariectomized rats increased serum levels of irisin, together with simultaneous prevention of osteoporotic changes. So, the present study suggested that the beneficial effects of swimming training in ovariectomized rats might be mediated through the stimulatory effect of irisin on bone formation.

\section{Recommendations:}

Further studies are required to clarify the effect of irisin administration on ovariectomized female rats with established osteoporotic changes.

\section{Acknowledgment:}

To Prof./Kamal El-Kashishy, Pathology Department, Faculty of Medicine, Zagazig University for performing the histopathological examination.

\section{References}

1- BOSTROM P., WU J., JEDRYCHOWSKI M.P., KORDE A., YE L., LO J.C., RASBACH K.A. and BOSTRÖM E.A.: A PGC1-alpha-dependent myokine that drives brown-fat-like development of white fat and thermogenesis. Nature, 481: 463-8, 2012.

2- AYDIN S., KULOGLU T. and AYDIN S.: Copeptin, adropin and irisin concentrations in breast milk and plasma of healthy women and those with gestational diabetes mellitus. Peptides, 47: 66-70, 2013.

3- ELSEN M., RASCHKE S. and ECKEL J.: Browning of white fat: Does irisin play a role in humans. J. Endocrinol., 222: $25-38,2014$

4- DUN S.L., LYU R.M., CHEN Y.H., CHANG J.K., LUO J.J. and DUN N.J.: Irisin-immunoreactivity in neural and non-neural cells of the rodent. Neuroscience, 240: 15562, 2013.

5- KELLY D.P.: Medicine. Irisin, light my fire. Science, 336: 42-3, 2012.

6- VARACALLO M.A. and FOX E.J.: Osteoporosis and its complications. Med. Clin. North Am., 98 (4): 817-31, 2014.

7- GOLOB A.L. and LAYA M.B.: Osteoporosis: Screening, prevention, and management. Med. Clin. North Am., 99: 587-606, 2015

8- JEE W.S and YAO W.: Overview: Animal models of osteopenia and osteoporosis. J. Musculoskelet. Neuronal Interact., 1: 193-207, 2001.

9- TOYOKAWA S., NISHIKAWA H., UEJI M., MOTEGI K. and KANO K.: Structural equation modeling of the relationship of bone mineral density and its risk factors in Japanese women. Environ. Health Prev. Med., 6: 416, 2001.

10- PAPAIOANNOU A., MORIN S., CHEUNG A.M., ATKINSON S., BROWN J.P., FELDMAN S., HANLEY D.A. and HODSMAN A.: 2010 clinical practice guidelines for the diagnosis and management of osteoporosis in Canada: Summary. C.M.A.J., 182 (17): 1864-73, 2010.

11-COSMAN F., De BEUR S.J., LEBOFF M.S., LEWIECKI E.M., TANNER B., RANDALL S. and LINDSAY R.: Clinician's guide to prevention and treatment of osteoporosis. Osteoporos. Int., 25: 2359-81, 2014.

12- DIGIROLAMO D.J., KIEL D.P. and ESSER K.A.: Bone and skeletal muscle: Neighbors with close ties. J. Bone Miner. Res., 28: 1509-18, 2013.

13- BOURRIN S., GHAEMMAGHAMI F., VICO L., CHAPPARD D., GHARIB C. and ALEXANDRE C.: Effect of a five-week swimming program on rat bone: A histomorphometric study. Calcif. Tissue Int., 51: 137-42, 1992.

14- EMSLANDER H.C., SINAKI M., MUHS J.M., CHAO E.Y., WAHNER H.W., BRYANT S.C., RIGGS B.L. and EASTELL R.: Bone mass and muscle strength in female college athletes (runners and swimmers). Mayo. Clin. Proc., 73: 1151-60, 1998.

15- OOI F.K., NORSYAM M.N., GHOSH A.K., SULAIMAN S.A., CHEN C.K. and HUNG L.K.: Effects of short-term swimming exercise on bone mineral density, geometry, 
and microstructural properties in sham and ovariectomized rats. J. Exer. Sci. Fit., 12: 80-7, 2014.

16- HART K.J., SHAW J.M., VAJDA E., HEGSTED M. and MILLER S.C.: Swim trained rats have greater bone mass, density, strength, and dynamics. J. Appl. Physiol., 91: 1663-8, 2001.

17- IRAHARA M., TAMURA T., MATUZAKI T., SAITO S., YASUI T., YAMANO S., KAMADA M. and AONO T.: Orexin-A suppresses the pulsatile secretion of luteinizing hormone via $[3$-endorphin. Biochm. Biophys. Res. Commun., 281: 232-6, 2001.

18- TEIXEIRAA A.M., TREVIZOLA F., COLPOA G., GARCIAC S. C., CHARÃOC M. and PEREIRAB R.P.: Influence of chronic exercise on reserpine-induced oxidative stress in rats: Behavioral and antioxidant evaluations. Pharmacol. Biochem. Behav., 88: 465-72, 2008.

19- MARCONDES F.K., BIANCHI F.J. and TANNO A.P.: Determination of the estrous cycle phases of rats: Some helpful considerations. Braz. J. Biol., 62: 609-14, 2002.

20- TIETZ N.W.: Clinical Guide to Laboratory Tests, 3 rd Edition, W.B. Saunders, Co., Philadelphia, 1995.

21- GINDLER H., POLLARD F.M. and MARTIN J.V.: Color imetric determination of serum calcium. Anal. Biochem., 20: 512, 1972.

22- GOLDENBERG H. and FERNFINDEZ A.: Colorimetric determination of serum phosphorus. Clin. Chem., 12: $871,1966$.

23- BELFIELD A. and GOLDBERG D.M.: Hydrolysis of adenosine monophosphates by acid phosphatases as measured by a continuous spectrophotometric assay. Biochem. Med., 4: 135-48, 1971.

24- DOSTER G.R., YORKE R.E. and RANDLE P.J.: Ashing procedures for biological materials. Current Science, 3: 206, 1969.

25- RAAB J.K., ALAN S.T. and DRURY W.: Histological methods for bone, 5 th ed., Oxford University Press, New York, Toronto, p.p. 185, 1991.

26- BANCROFT D. and COOK J.: Organic chelating agents for decalcification of bone. Stain technology, 28: 285, 1984.

27- MATSUBARA M., SAKATA I., WADA R., YAMAZAKI, M., INOUE K. and SAKAI T.: Estrogen modulates ghrelin expression in the female rat stomach. Peptides, 25: 28997, 2004.

28- FERNANDEZ-FERNANDEZ R., MARTINI A.C., NAVARRO V.M., CASTELLANO J.M., DIEGUEZ C., AGUILAR E., PINILLA L. and TENA-SEMPERE M.: Novel signals for the integration of energy balance and reproduction. Mol. Cell Endocrinol., 254: 127-32, 2006.

29- OUYANG L., ZHANG Q., RUAN X., FENG Y. and WANG X.: Treatment effect of Bushen Huayu extract on postmenopausal osteoporosis in vivo. Exp. Ther. Med., 7: 1687-90, 2014.

30- PALERMO A., STROLLO R., MADDALONI E., TUCCINARDI D., ONOFRIO L., BRIGANTI S., DEFEUDIS G., PASCALIS M. and LAZZARO M.: Irisin is associated with osteoprotic fractures independently of bone mineral density, body composition or daily physical activity. Clin. Endocrinol., 82: 1-5, 2014.

31- KAWAKITA S., MAROTTA F., NAITO Y., GUMASTE U., JAIN S., TSUCHIYA J. and MINELLI E.: Effect of an isoflavones-containing red clover preparation and alkaline supplementation on bone metabolism in ovariectomized rats. Clin. Interv. Aging, 4: 91-100, 2009.

32- HEANEY R.P., RECKER R.R., STEGMAN M.R. and MOY A.J.: Calcium absorption in women: Relationships to calcium intake, estrogen status and age. J. Bone Miner. Res., 4: 469-75, 1989.

33- SHIRAISHI A., TAKEDA S., MASAKI T., HIGUCHI Y., UCHIYAMA Y., KUBODERA N., SATO K., IKEDA K., NAKAMURA T., MATSUMOTO T. and OGATA E.: Alfacalcidol inhibits bone resorption and stimulates formation in an ovariectomized rat model of osteoporosis: Distinct actions from estrogen. J. Bone Miner. Res., 15: 4, 2000.

34- SALEH N.K. and SALEH H.A.: Olive Oil effectively mitigates ovariectomy induced osteoporosis in rats. BMC Complement. Altern. Med., 11: 10, 2011.

35- ABUOHASHISH H.M., AHMED M.M., AL-REJAIE S.S and ELTAHIR K.E.: Antidepressant bupropion exerts alleviating properties in an ovariectomized osteoporotic rat model. Acta Pharmacologica Sinica, 36: 209-20, 2015.

36- RACHNER T.D., KHOSLA S. and HOFBAUER L.C.: Osteoporosis: Now and the future. Lancet, 377: 1276-87, 2011.

37- JILKA R.L.: Cytokines, bone remodeling, and estrogen deficiency. Bone, 23: 75-81, 1998.

38- PACIFICI R.: Cytokines, estrogen, and postmenopausal osteoporosis-the second decade. J. Endocrinol., 139: 2659$61,1998$.

39- HUGHES D.E., DAI A., TIFFEE J.C., LI H.H., MUNDY G.R. and BOYCE B.F.: Estrogen promotes apoptosis of murine osteoclasts mediated by TGF-b. Nat. Med., 2: 1132-6, 1996.

40- MANOLAGAS S.C., WEINSTEIN R.S., BELLIDO T. and BODENNER D.L.: Opposite effects of estrogen on the life span of osteoblasts/osteocytes vs. osteoclasts in vivo and in vitro: An explanation of the imbalance between formation and resorption in estrogen deficiency. J. Bone Miner. Res., 14: S169, 1999.

41- KWAK E.J., LEE Y.S. and CHOI E.M.: Effect of magnolol on the function of osteoblastic MC3T3 E1 cells. Mediators Inflamm., 2012: 829650-6, 2012.

42- FERRETTI M., BERTONI L., CAVANI F., ZAVATTI M., RESCA E. and CARNEVALE G.: Influence of ferutinin on bone metabolism in ovariectomized rats. II: Role in recovering osteoporosis. J. Anat., 217: 48-56, 2010.

43- ENGIN-ÜSTÜN Y., ÇA GLAYAN E.K., GÖÇMEN A.Y. and POLAT M.F.: Postmenopausal Osteoporosis Is Associated with Serum Chemerin and Irisin but Not with Apolipoprotein M Levels. J. Menopausal. Med., 22 (2): 76-99, 2016.

44- YAN J., LIU H.J., GUO W.C. and YANG J.: Low serum concentrations of Irisin are associated with increased risk of hip fracture in Chinese older women. Joint Bone Spine, 85 (3): 353-8, 2018. 
45- HUH J.Y., PANAGIOTOU G., MOUGIOS V., BRINKOETTER M., VAMVINI M.T. and SCHNEIDER B.E.: FNDC5 and irisin in humans: I. Predictors of circulating concentrations in serum and plasma and II. mRNA expression and circulating concentrations in response to weight loss and exercise. Metabolism, 61: 1725-38, 2012.

46- ANASTASILAKIS A.D., POLYZOS S.A., MAKRAS P., GKIOMISI A., BISBINAS I. and KATSAROU A.: Circulating irisin is associated with osteoporotic fractures in postmenopausal women with low bone mass but is not affected by either teriparatide or denosumab treatment for 3 months. Osteoporos. Int., 25: 1633-42, 2014.

47- MIYAMOTO-MIKAMI E., SATO K., KURIHARA T., HASEGAWA N., FUJIE S. and FUJITA S.: Endurance training-induced increase in circulating irisin levels is associated with reduction of abdominal visceral fat in middle-aged and older adults. PLoS One, 10 (3): e0120354, 2015.

48- ZUGEL M., QIU S., LASZLO R., BOSNYA E., WEIGT C., MULLER D., DIEL P., STEINACKER J.M. and SCHUMANN E.: The role of sex, adiposity, and gonadectomy in the regulation of irisin secretion. Endocrine, 54: 101-10, 2016

49- SINGHAL V., LAWSON E.A., ACKERMAN K.P., FAZELI P.K., CLARKE H., LEE H., EDDY K. and MARENGI D.A.: Irisin levels are lower in young amenorrheic athletes compared with eumenorrheic athletes and nonathletes and are associated with bone density and strength estimates. PLoS One, 9 (6): e100218, 2014.

50- GAO S., CHENG Y., ZHAO L., CHEN Y. and LIU Y.: The relationships of irisin with bone mineral density and body composition in PCOS patients. Diabetes Metab. Res. Rev., 32: 421-8, 2016.

51- COLAIANNI G., NOTARNICOLA A., SANESI L., BRUNETTI G., LIPPO L., CELI M., MORETTI L., PESCE V., VICENTI G. and MORETTI B.: Irisin levels correlate with bone mineral density in soccer players. J. Biol. Regul. Homeost. Agents, 31 (4 Suppl 1): 21-8, 2017.

52- WU L.F., ZHU D.C., TANG C.H., GE B., SHI J., WANG B.H., LU Y.H., HE P., WANG W.Y., LU S.Q., ZHONG J., ZHOU X. and ZHU K.: Association of Plasma Irisin with Bone Mineral Density in a Large Chinese Population Using an Extreme Sampling Design. Calcif. Tissue Int., 103 (3): 246-51, 2018.

53- PIRI F., MOAYERI A.K., DERAKHSHAN S., SAYEHMIRI K. and ARDESHIR M.: Evaluating the effect of exercise and nutrition on bone density in rats. J. Bas. Res. Med. Sci., 3: 15-20, 2016.

54- FIGARD H., MOUGIN F., GAUME V. and BERTHELOT A.: Combined intervention of dietary soybean proteins and swim training: Effects on bone metabolism in ovariectomized rats. J. Bone Miner. Metab., 24: 206-12, 2006.

55- YEH J.K. and ALOIA J.F.: Effect of physical activity on calcitropic hormones and calcium balance in rats. Am. J. Physiol., 258: 263-8, 1990.

56- BORRER K.T.: Physical activity in the prevention and amelioration of osteoporosis in women. Sport Med., 235: 779-830, 2005.

57- VEIGH J.M., KINGSLEY S., GRAY D. and LORAM L.C.: Swimming enhances bone mass acquisition in growing female rats. J. Sports Sc. Medi., 9: 612-9, 2010.
58- KIM C.S. and PARK D.H.: Effects of chronic NH4Cl dosage and swimming exercise on bone metabolic turnover in rats. J. Physiol. Anthropol. Appl. Human Sci., 24: 595600, 2005

59- SWISSA-SIVAN A., AZOURY R., STATTER M., LEICHTER I., NYSKA A., NYSKA M., MENCZEL J. and SAMUELOFF S.: The Effect of Swimming on Bone Modeling and Composition in Young Adult Rats. Calcif. Tissue Int., 47: 173-7, 1990.

60- CAMOZZI V., TOSSI A., SIMONI E., PAGANI F., FRAN CUCCI C.M. and MORO L.: Role of biochemical markers of bone remodeling in clinical practice. J. Endocrinol. Invest., 30: 13-7, 2007.

61- MAREDZIAK M., SMIESZEK A., CHRZASTEK K., BASINSKA K. and MARYCZ K.: Physical activity increases the total number of bone-marrow-derived mesenchymal stem cells, enhances their osteogenic potential, and inhibits their adipogenic properties. Stem. Cells Int., 2015: 379093, 2015.

62- LU Y., LI H., SHEN S.W., SHEN Z.H., XU M., YANG C.J., LI F., FENG Y.B., YUN J.T., WANG L. and QI H.J. Swimming exercise increases serum irisin level and reduces body fat mass in high fat-diet fed Wistar rats. Lipids Health Dis., 15: 93, 2016.

63- TIMMONS J.A., BAAR K., DAVIDSEN P.K. and ATHERTON P.J.: Is irisin a human exercise gene? Nature, 488: 9-10, 2012.

64- JAFARI M. and FARZNEGHI P.: The effect of regular aerobic exercise combined with consuming garlic extract on rest levels of plasma irisin and FNDC5 of the heart tissue and muscle of aged rats. J. UMP, 3: 286-91, 2015.

65- FAIN J.N., COMPANY J.M., BOOTH F.W., LAUGHLIN M.H. and PADILLA J.: Exercise training does not increase muscle FNDC5 protein and mRNA expression in pigs. Metabolism, 62: 1503-11, 2013.

66- QIU S., CAI X., SUN Z., SCHUMANN U., ZÜGEL M. and STEINACKER J.M.: Chronic Exercise Training and Circulating Irisin in Adults: A Meta-Analysis. Sports Med., 45: 1577-88, 2015.

67- BELVIRANLI M., OKUDAN N. and KARAKUYU N.: The association between irisin levels, element distribution and oxidative stress markers in adolescent swimmers. Horm. Mol. Biol. Clin. Investig., 16; 34 (3), 2018.

68- COLAIANNI G., CUSCITO C., MONGELLI T., ORANGER A., MORI G., BRUNETTI G., COLUCCI S., SAVERIO CINTI S. and GRANO M.: Irisin enhances osteoblast differentiation in vitro. Int. J. Endocrinol., 2014: 90218693, 2014.

69- TSUKAHARA N., TODA A., GOTO J. and EZAWA I.: Cross-sectional and longitudinal studies on the effect of water exercise in controlling bone loss in Japanese postmenopausal women. J. Nutr. Sci. Vitaminol., 1: 37-47, 1994.

70- KEMPER C., De OLIVEIRA R.J., BOTTARO M., MORENO R., BEZERRA L.M.A., GUIDO M. and De FRANC N.M.: Effects of swimming and resistance training on bone mineral density of older women. Rev. Bras. Med. Esporte, 15: 10-3, 2009. 
71- PALIOLOGOA T., SHIMANOA R.C., SHIMANOA A.C., MACEDOA A.P., FALCAIA M.J. and ISSAB J.P.: Effects of swimming associated with risedronate in osteopenic bones: An experimental study with ovariectomized rats. Micron, 78: 40-4, 2015.

72- QIAO X., NIE Y., MA Y., CHEN Y., CHENG R., YIN W., HU Y., XU W. and XU L.: Irisin promotes osteoblast proliferation and differentiation via activating the MAP kinase signaling pathways. Sci. Rep., 6: 18732, 2016.

73- MA Y., QIAO X., ZENG R., CHENG R., ZHANG J., LUO Y., NIE Y., HU Y., YANG Z., ZHANG J., LIU L., XU W., XU C.C. and XU L.: Irisin promotes proliferation but inhibits differentiation in osteoclast precursor cells. FASEB J. 17: fj201700983RR, [Epub ahead of print], 2018.

\section{تآثير السباحة على مستويات الآيرسين فى مصل الدم أدمام

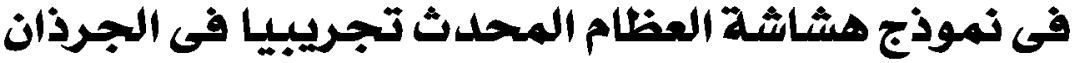

الآيرسين هو آحد اليتيدات المكتشفة حديثا والمفرزة من العضلات، والذى إرتبط بالعديد من الآمراض الناتجة عن إضرابات التمثيل

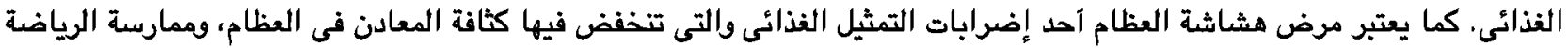

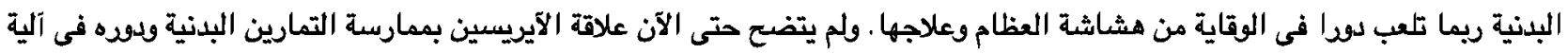

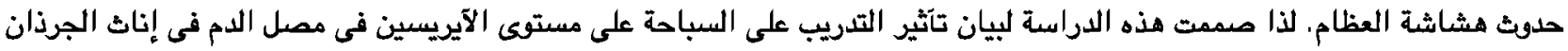
البيضاء المحدث بها تجريبيا نموذج هشاشة العظام.

وقد آجريت الدراسة على عدد ^ع من إناث الجرذان البيضاء البالغة، والتى قسمت إلى آربع مجموعات: مجموعة ضابطة، ومجموعة مدربة الئية

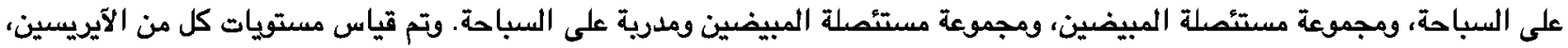
والإستراديول، والكالسيوم، والفوسفور، والآلكلين فوسفاتيز فى مصل الدم، ومستويات كل من الكالسيوم والفوسفود في العظام، وقنت رماد

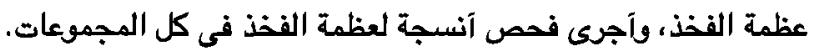

وقد آثّمر هذا البحث عن العديد من النتائج وهى: وجود زيادة ذات دلالة إحصائية فى مستويات الآيريسين فى مصل الدم في المجموعة

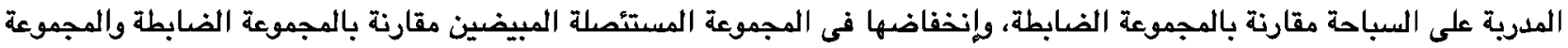

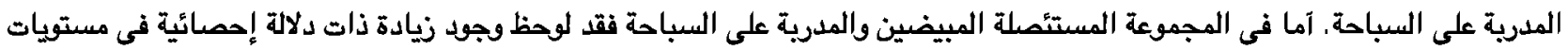

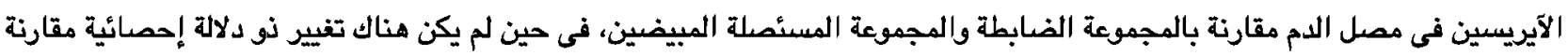

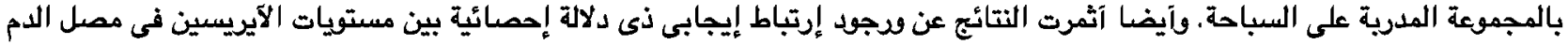

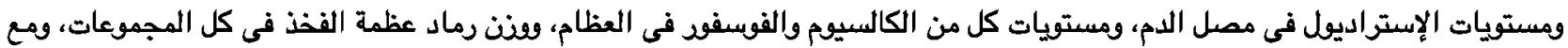
مستوى الآلكلين فوسفاتيز في مصل الدام فقط فى المجموعات المدربة على السباحة.

ونستتج من هذه الدراسة: آن التريب على السباحة آحثث زيادة فى مستويات الآيريسين فى مصل الدم فى الجرذان المستئصلة المبيضين،

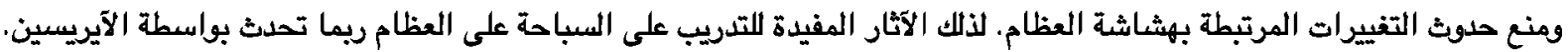

